\title{
The Memorial Inscriptions of
}

\section{AL-Amir Jani Beg AL-Dawadar}

\author{
AL-Ashrafi mosque
}

(Al-JanabkiyaMosque)

Reserche Prepared by the Resercher

\section{Hussein Mohammed Ahmed Osman}

\author{
Submitted to Faculty of Arts, \\ Minia University
}

]2018AD/1440AH

- Study Importance, the Reasons for its Choice and Study its Objectives:

- The reasons for selecting the subject and its importance in the field of archaeological studies and tourism guidance:

1- The desire to collect all the inscriptions of this monument in one study, Tracing these inscriptions in

2- various references and studies that dealt with those architectural monuments is difficult and exhausting, so, if they are compiled in one study, it will be easy to tackle them.

2- The library of tourist guides lacks similar studies that deal with archaeological inscriptions on monuments as a guiding material.

3- The desire to highlight the importance of these inscriptions in shedding light on the era they represent in general, as they are considered material documents that do not accept questioning or controversy in their information. 
4- Increasing the archaeological and tourist awareness of the tour guides and all the workers in the field of guidance in terms of the value of these commemorative inscriptions represented by the paintings and panels. The aim is to take care and preserve them as masterpieces of art which constitute a fundamental aspect of the Islamic cultural and artistic heritage. In addition, they include information indispensible to every tourist guide.

5-To highlight the importance of inscriptions in general and the foundational inscriptions in particular for the easy presentation of their archaeological material and highlighting their importance in the field of tourism guidance.

6-To increase the archaeological and tourist awareness of citizens and tour guides in order to maximize the role of monuments and its archaeological importance. The highlight of such vital areas and their monuments maximize their respect, interest and preservation in order to maximize benefitting from them. This is one of the main objectives of tourism guidance.

7-To identify the types of different scripts and stages of their development, the characteristics of each type, the periods of their prosperity and influences, as well as knowledge of the types of raw materials used in recording these inscriptions on the monuments of the street. This is in addition to identifying the most used scripts in each era.

8-To address the titles of the inscriptions under investigation and their prosperity in the social life, each in its respective era.

9-To study the contents of these inscriptions, as they provide information on the economic and political situation in the different periods of construction.

10 - Facilitate the task of tour guides in terms of reading these inscriptions, knowledge of their content and the distinction between the types of scripts. It is noted that many tourist guides - especially the graduates of the colleges of tourism and archeology - did not pay attention to these inscriptions, which requires focus as well as the presence of specialists. In addition, these inscriptions represent a fertile guidance material as they enrich the guide's archaeological information. 


\section{$\underline{\text { AL-Amir Jani Beg AL-Dawadar AL-Ashrafi : }}$}

He was Amir Sayf al-Din Jani Beg ibn Abdullah ibn Mahmoud Shah alAshrafi al-Dawadar, born in (805 AH/ 1402 AD). He was a Mamluk of Sultan alAshraf Barsbay who bought him when he was young, when Barsbay was the viceroy of the Sham. Jani Beg suffered a lot with Barsbay from imprisonment and exile. When Barsbay acceded to throne in (825-842 AH / 1422-1438 AD), he released him and upgraded him to the position of Amir 'Ashra in (826 AH / 1423 AD). Jani Beg assumed several posts until he became Amir Tablakhana in Muharram in 826 AH / January 1433 AD and then a Khazendar. In Sha'aban of $826 \mathrm{AH}$, Sultan Barsbay sent him to be a ruler over three emirs of the Sham, which refers to Barsbay's great trust in him.

Then, he became a dawadarII on the $16^{\text {th }}$ of Dhu al-Qi'dah of the same year. The position of dawadar, in his time, became prominent as a result of the sanctity and merits he bestowed upon it. Later, he became the Lala (instructor) of Sultan Barsbay's sons. He became so influential and privileged that al-Malik alAshraf let him administer the affairs of his country until he became one of the greatest men of state. As a result, Sultan Barsbay feared of his increasing influence, so he poisoned him. Jani Beg died - as atated by al-Maqrizi- on Thursday, 27 Rabee Al-Awwal, 831 AH / January 1428 AD, while Ibn Taghri birdi said that he died on Thursday, 23 Rabi Al-Awwal at the age of 25 . He was buried at the mausoleum of this madrassa.

Then his remains were transferred to a mausoleum at the cemetery of Mamluks, next to the mausoleum of al-Ashraf Barsbay (Monument No. 122). He was said to be short, green-eyed, small-bearded, elaborate, righteous, generous and religious. In addition, he was handsome but he was not cultured. He was fond of hunting. He ordered building many significant establishments such as a square in Souq al-Waraqin in $828 \mathrm{AH} / 1424 \mathrm{AD}$, his mosque in the area of al-Migharbilin ca. 828-830 $\mathrm{AH} /$ 1424-1426 $\mathrm{AD}$, a mausoleum in the eastern Qarafah to the 
northeast of Barsbay's mausoleum in 831/1427 AD and a Qaysariya in the area between al-Mu'izz Street and the square that no longer exist ${ }^{1}$.

\section{Brief Overview on the Monument:}

Monument No :119.

Dated :830 AH/ 1426-1427 AD.

Location: Al-Megharbilin Street, formerly known as Zahir Bab Zuwaila and al-Kharq. It was also Known as Souq al-Qerabiyin and Khatt alMuaziniyin $^{2}$.

Its construction was accomplished on Friday $2^{\text {nd }}$ Ramadan in $830 \mathrm{AH} /$ $1427 \mathrm{AD}^{3}$. It is a magnificent mosque with a huge façade that included the minaret and the main entrance. Its eastern side had a sabil that demolished now. It also had a small square mausoleum compared to its counterparts ${ }^{4}$. The southern part has a door of the ablution place that is adjacent to the basin of watering livestock ${ }^{5}$. In conformity with the architectural description and planning, this building was a madrassa, as al-Sakhawy stated that it was a Hanafi madrassa that had Sufis. The same was confirmed by Ibn Taghri birdi, al-Sirāfi, Ibn Iyas and Ali Mubarak ${ }^{6}$.

While al-Maqrizi stated that it was a Khanqah ${ }^{7}$ and mentioned in is work "al-Selouk" that it was a mosque. This view was supported by Van Berchem, Meheren and Creswell ${ }^{8}$. However, its foundational text confirmed that it was a mosque, which made Berchem prefer that these buildings were named according to their function and purpose and not their planning or style 9 . The Committee began the works of its renovation and restoration in 1909 AD up to $1911 \mathrm{AD}$. It was also renovated in the reign of King Farouk $I$ and its marble floors were repaired $^{10}$. The layout of this mosque is similar to that of Madrassa of al-Qadi Abdul Basit, Madrassa of Abdul Ghani al-Fakhri and Madrassa of Barsbay in alAshrafiyah, which predicts that their architect and Shad was the same ${ }^{11}$.

\section{The Current Outline of the Mosque ${ }^{12}$ :}

The mosque occupies a rectangular area and has three external stone facades. The south-western façade is replaced with a modern house now ${ }^{13}$. The north-eastern façade is characterized by its hanging façade ${ }^{14}$ that overlooks Haret al-Janaskeya (a lane) .The south-eastern façade overlooks Haret al-Jāmi' and has a door leading to residential apartments ${ }^{15}$. There is a door in the south-western side that leads to the ablution place and a staircase leading to the roof ${ }^{16}$. As for the main façade, it locates in the north-western side and the main entrance to the 
mosque is located on its northern side. It is a monumental entrance with a lobed arch. The minaret locates toits right part - in qulla style- and the facade of mausoleum ${ }^{17}$. The main entrance has two miksalas and wooden two-leafs of a laminated door in their midst. The name and titles of the founder are inscribed over the door ${ }^{18}$.

To the right of the main entrance there is a door opening leading to the mausoleum ${ }^{19}$. The main entrance leads to the entrance doorqa'a, which is square and with wooden roof. It has two doors, the left - currently blocked - leads to the room of sabil (that no longer exists) and the right leads to a refracted portico, a part of which is covered while the other is left open. To the right of this portico, there is a wooden two-leaf door opening leading to the mosque's $\operatorname{sahn}^{20}$. It is a square sahn with a low floor covered with a thick cloth leading to the covered roof. A shallow dome suspended from it. It was common in the Circassianera ${ }^{21}$. In addition, it is surrounded by four wooden two-leaf doors ${ }^{22}$. The first of which locates to the northern corner, it is the entry door. The second locates to the western corner and leads to the mausoleum. The third locates to the southern corner and leads to the ablution place. As for the fourth, it locates to the eastern corner and leads to the annexes of the mosque ${ }^{23}$.

It is surrounded by four Iwans, the largest of which is the qibla Iwan, with the entrance to mihrab. The iwans overlook the sahn and they have stone arches with alternate colors (usually the red and white). In addition, the iwans are covered with wooden ceilings decorated with geometric and foliate motifs. The mausoleum occupies the western corner of the mosque area and consists of a square space covered by a dome resting on several stalactites. The external part of the mausoleum is adorned with zigzag forms(Dalaiat) ${ }^{24}$.

\section{The Memorial Inscriptions of the Mosque ${ }^{25}$ :}

The mosque has a number of inscriptions as follows:

The inscription below the arch of the main entrance to the mosque:

It locates on top of the arch of the main entrance door of the mosque- over the stalactites of the window, on top of the door of the entrance in the main northwestern façade. Below the lobed arch which crowns the façade of the mosque, there is a stone band of inscriptions with the dimensions of $2.65 \mathrm{~m} \times 60 \mathrm{~cm}$. it has high-relief inscription in thuluth on a floriated background. It is a Qur'anic text with its conformation as follows.: see pl No. (1).

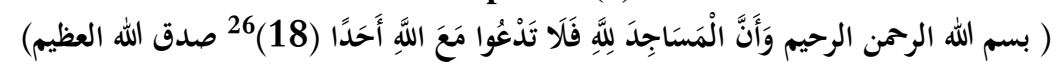

It reads:("In the name of Allah, the Most Gracious and the Most Merciful" And [He revealed] that the masjids are for Allah, so do not invoke with Allah anyone. God Almighty has spoken the truth).

The inscription above the entrance door of the mosque: 
The entrance door is topped by a copper-castings window that is topped also by two marble squares: $70 \mathrm{~cm} \times 70 \mathrm{~cm}$ in size, i.e., a square in each side. Each of which has an inscription below the previous one but the left is missed. However, the right square has an inscription in square kufic calligraphy ${ }^{27}$ of Tawhid (Monotheism) and al-Resala al-Muhammadiya (Muhammad's Message) in black on a white floor. It is as follows: see pl No. (2).

$$
\text { (لا اله الا الله محمد رسول الله ارسله بالهدى ودين الحق }
$$

It reads:(la ilaha illa I'llah, Muhammadun rasul Allah, Arsalahu Bil Huda wa Din al-Haq)which means that:(There is no god but Allah, Muhammad is the Messenger of Allah, sent by Guidance and the Religion of Truth).

Inscription above the two Maksalas of the main entrance door of the mosque:

It is a stone band of inscriptions in high-relief thuluth on a floriated background. It is a Qur'anic text followed by the foundational text of the mosque on both sides of its main entrance. The dimensions of each band are $3.32 \mathrm{~m} \times 75 \mathrm{~cm}$. The text has the conformation signs as follows: see pl No. (3).

The Right Side:

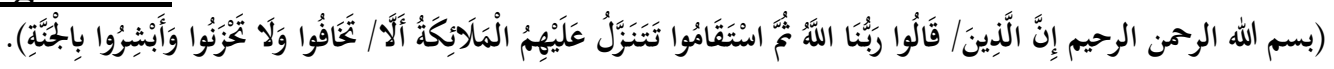

The Left Side:

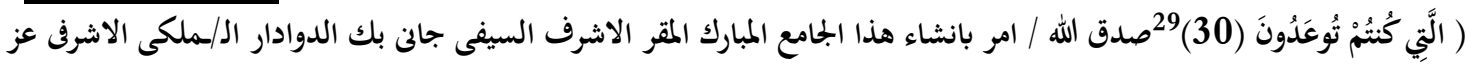

$$
\text { نصره بتاريخ شهور سنة ثلاثين وثمان ماية ) }
$$

It reads:(In the name of Allah, the Most Gracious and the Most Merciful" Indeed, those who have said, "Our Lord is Allah" and then remained on a right course - the angels will descend upon them, [saying], "Do not fear and do not grieve but receive good tidings of Paradise, which you were promised. God has spoken the truth Amara bi-'insha' haza al-Jāmi' al-mubarak al-maqar al-Ashraf al-Sayfi Jani Beg alDawadar al-Malaki al-Ashrafi Azz aNasrah bitarikh shuhur sanat Thalathin wathamani-mayah).

Inscription on the Bukhariyya in the center of the mosque main door. It locates on both shutters of the door:

It is a copper band of inscriptions in dimensions $92 \mathrm{~cm} \times 23 \mathrm{~cm}$. it can be found on the Bukhariyya (metal decorative unit) in the the center of the door shutters. It is incised in the copper in thuluth calligraphy as follows. Text of the right Shutter: (امر بانشاء هذا الباب المباركالمقر )

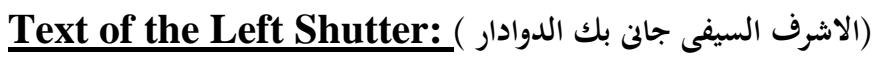

It reads: (Amara bi-'insha' haza al-bab al-mubarak al-maqar Al-Ashraf al-Sayfi Jani Beg al-Dawadar).which means that: (This blessed door was established by orders of al-maqar Al-Ashraf al-Sayfi Jani Beg al-Dawadar). 


\section{Inscription on the dome drum from Exterior:}

It extends around the drum of the mausoleum from outside -on top of the dome windows and beneath itsrattles (دلايات). It is a stone band of inscriptions $(14.61 \mathrm{~m} \times 35 \mathrm{~cm})$ in high-relief thuluth of a Qur'anic text as follows: see pl No. (4).

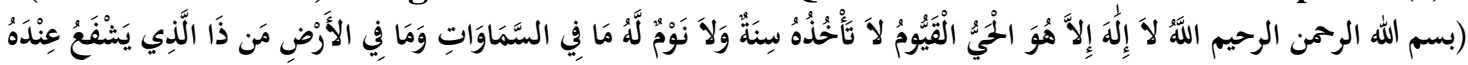

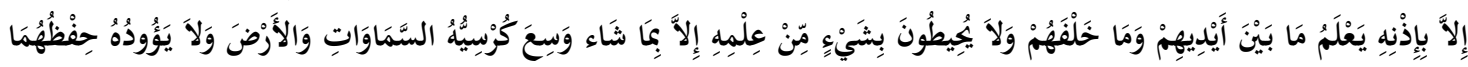

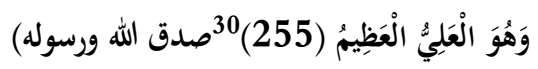

It reads:("In the name of Allah, the Most Gracious and the Most Merciful" Allah there is no deity except Him, the Ever-Living, the Sustainer of [all] existence. Neither drowsiness overtakes Him nor sleep. To Him belongs whatever is in the heavens and whatever is on the earth. Who is it that can intercede with Him except by His permission? He knows what is [presently] before them and what will be after them, and they encompass not a thing of His knowledge except for what He wills. His Kursi extends over the heavens and the earth, and their preservation tires Him not. And He is the Most High, the Most Great. Sadaqa Allah wa Rasuluh)which means that Allah and His Messenger Has said the Truth).

\section{Inscription around the minaret ${ }^{31}$ :}

It is a stone band of inscriptions in high-relief thuluth of a Qur'anic text that reads: see pl No. (5).

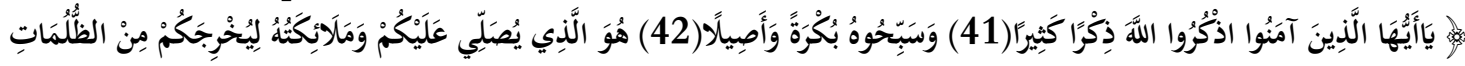

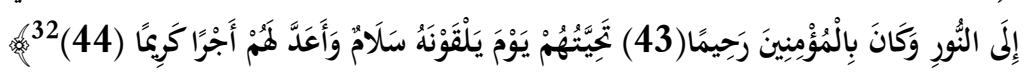

It reads: (O you who have believed, remember Allah with much remembrance And exalt Him morning and afternoon. It is He who confers blessing upon you, and His angels [ask Him to do so] that He may bring you out from darknesses into the light. And ever is He, to the believers, Merciful. Their greeting the Day they meet Him will be, "Peace." And He has prepared for them a noble reward). 


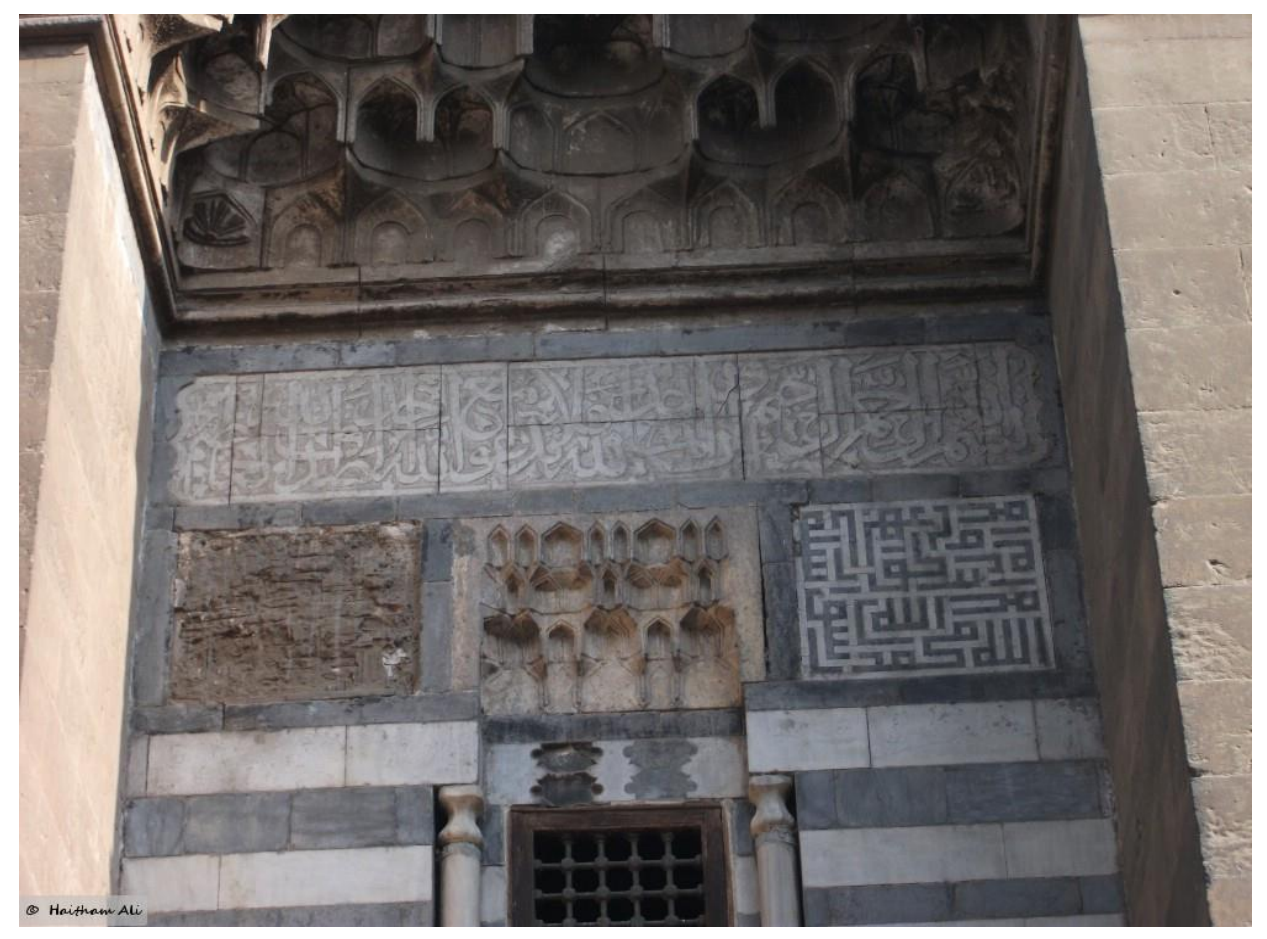



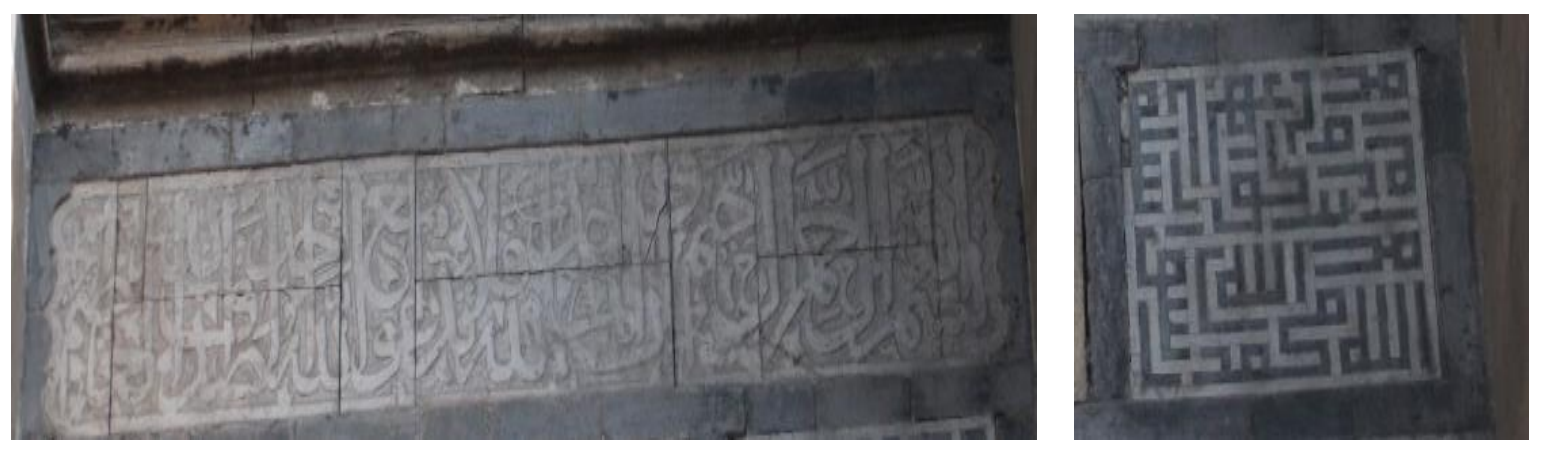

PL (1) : Cairo, Al-Megharbilin Street, the era of the Circassian Mameluke, al-Amir Jani Beg alDawadar mosque, a Qur'anic text, a stone band of inscriptions with the dimensions of $2.65 \mathrm{~m} \mathrm{x}$ $60 \mathrm{~cm}$. It locates on top of the arch of the main entrance door of the mosque-over the stalactites of the window, on top of the door of the entrance in the main north-western façade, in high relief Thuluth, on a floriated background, 830 AH/ 1426-1427 AD.

PL (2) : Cairo, Al-Megharbilin Street, the era of the Circassian Mameluke, al-Amir Jani Beg alDawadar mosque, a square kufic calligraphy of Tawhid (Monotheism) and al-Resala alMuhammadiya (Muhammad's Message), in a marble squares: $70 \mathrm{~cm} \times 70 \mathrm{~cm}$ in size, in top of The main entrance door, in black on a white floor, $830 \mathrm{AH} / 1426-1427 \mathrm{AD}$.

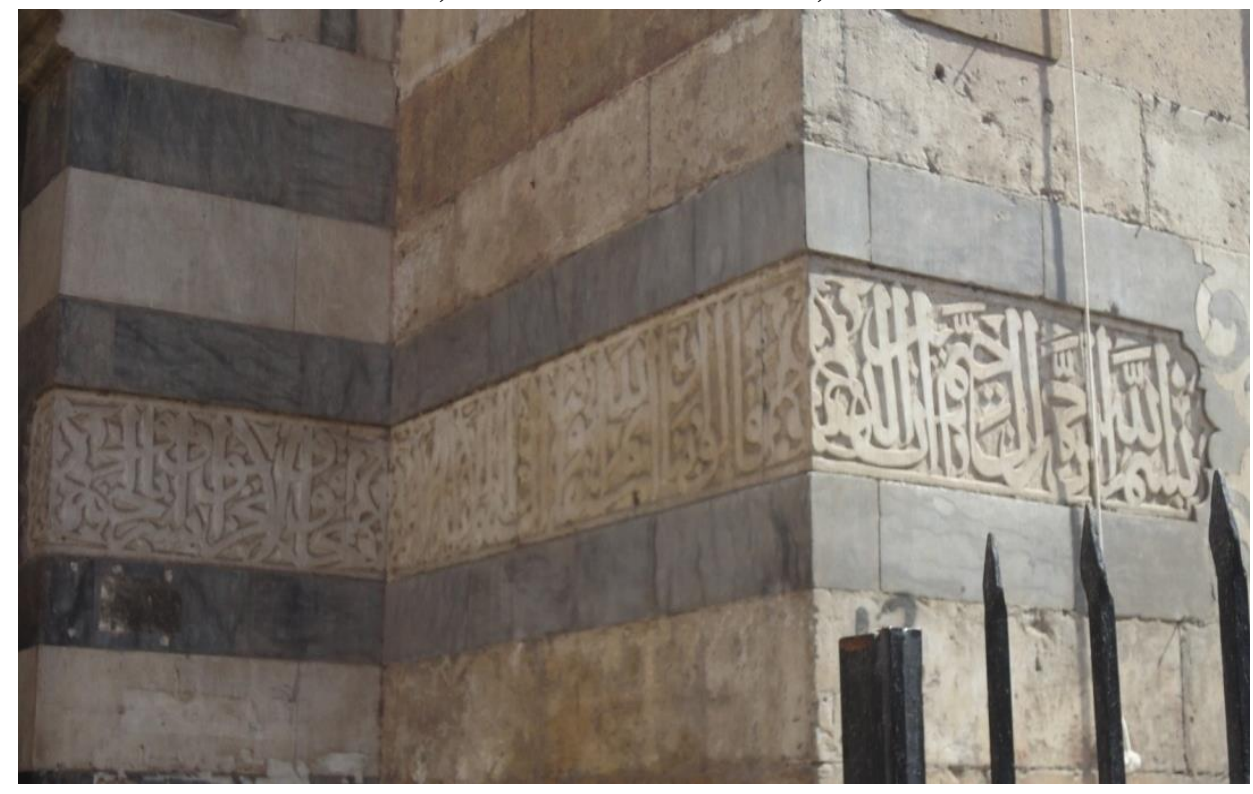




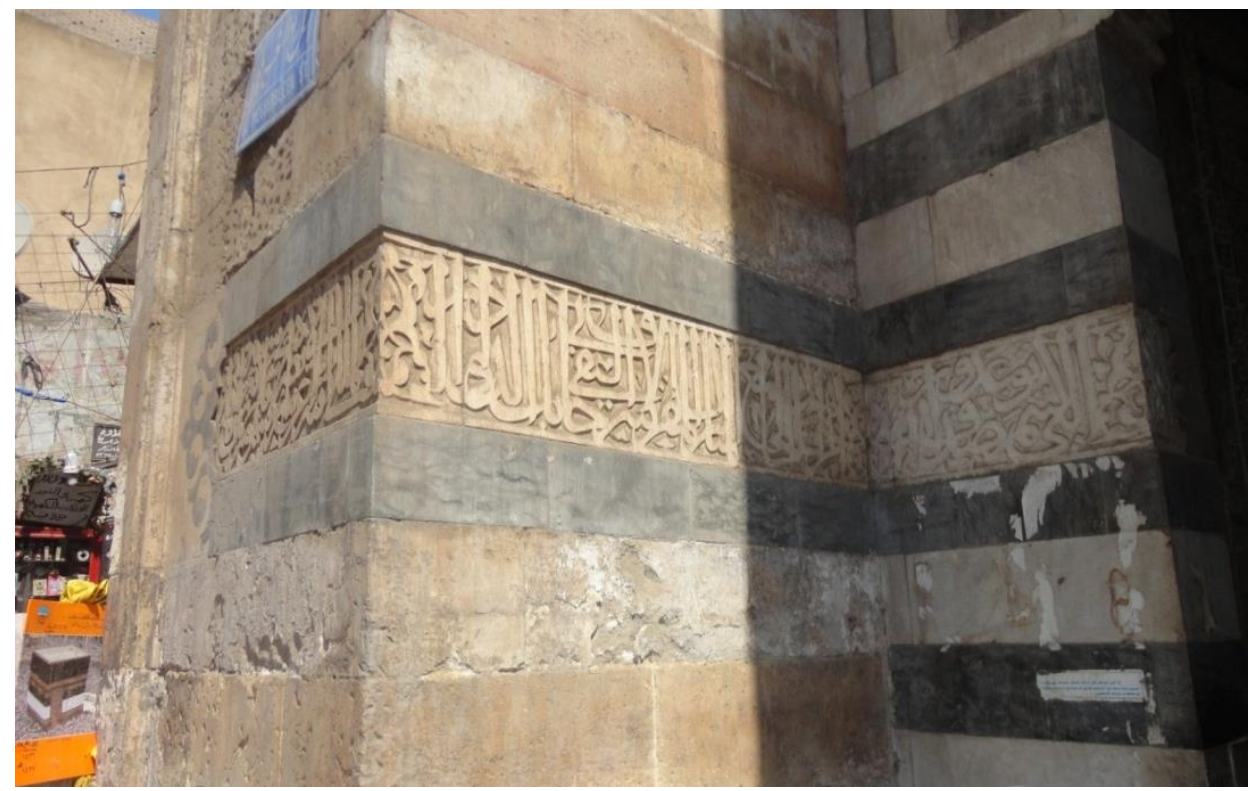

PL (3) : Cairo, Al-Megharbilin Street, the era of the Circassian Mameluke, al-Amir Jani Beg al-

Dawadar mosque, It is a stone band of inscriptions in high-relief thuluth on a floriated background. It is a Qur'anic text followed by the foundational text of the mosque on both sides of its main entrance. The dimensions of each band are

$3.32 \mathrm{~m} \times 75 \mathrm{~cm}, 830 \mathrm{AH} / 1426-1427 \mathrm{AD}$.

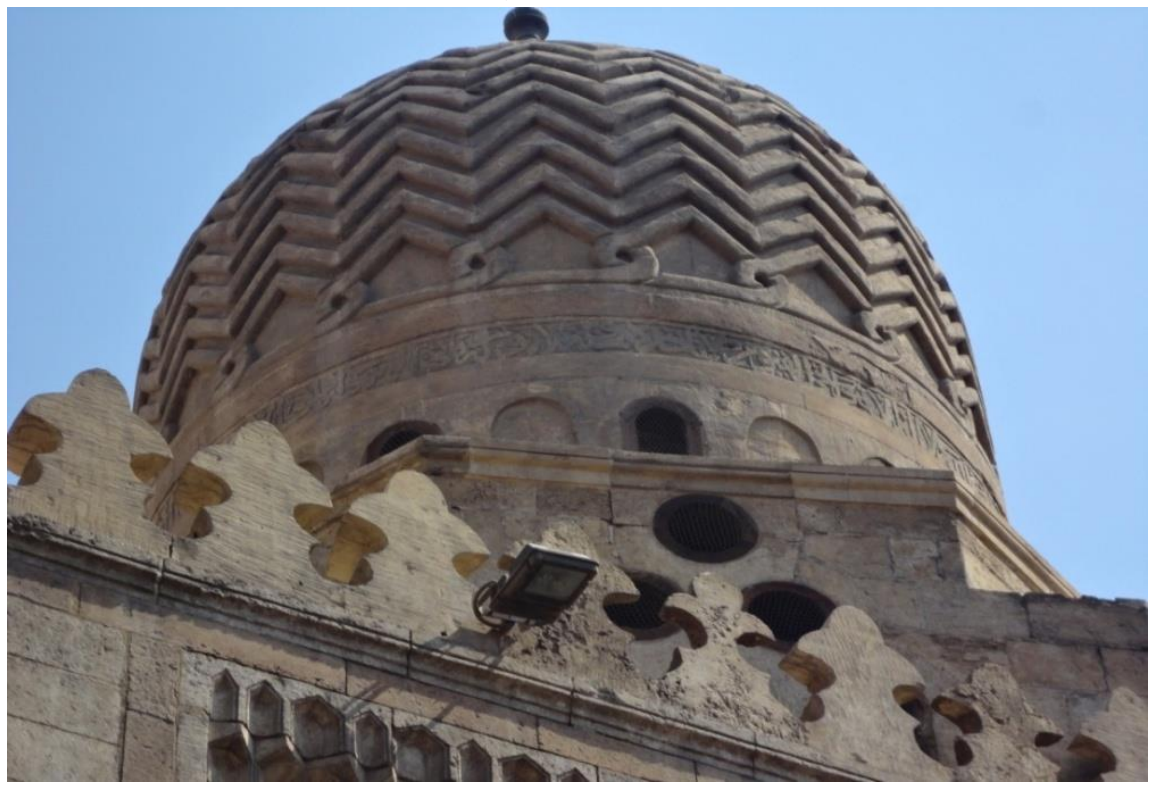

PL (4): Cairo, Al-Megharbilin Street, the era of the Circassian Mameluke, al-Amir Jani Beg alDawadar mosque, It is a stone band of inscriptions $(14.61 \mathrm{~m} \times 35 \mathrm{~cm})$ in high-relief thuluth of a Qur'anic text, on the dome drum of the mausoleum from Exterior,830AH/1426-1427 AD. 


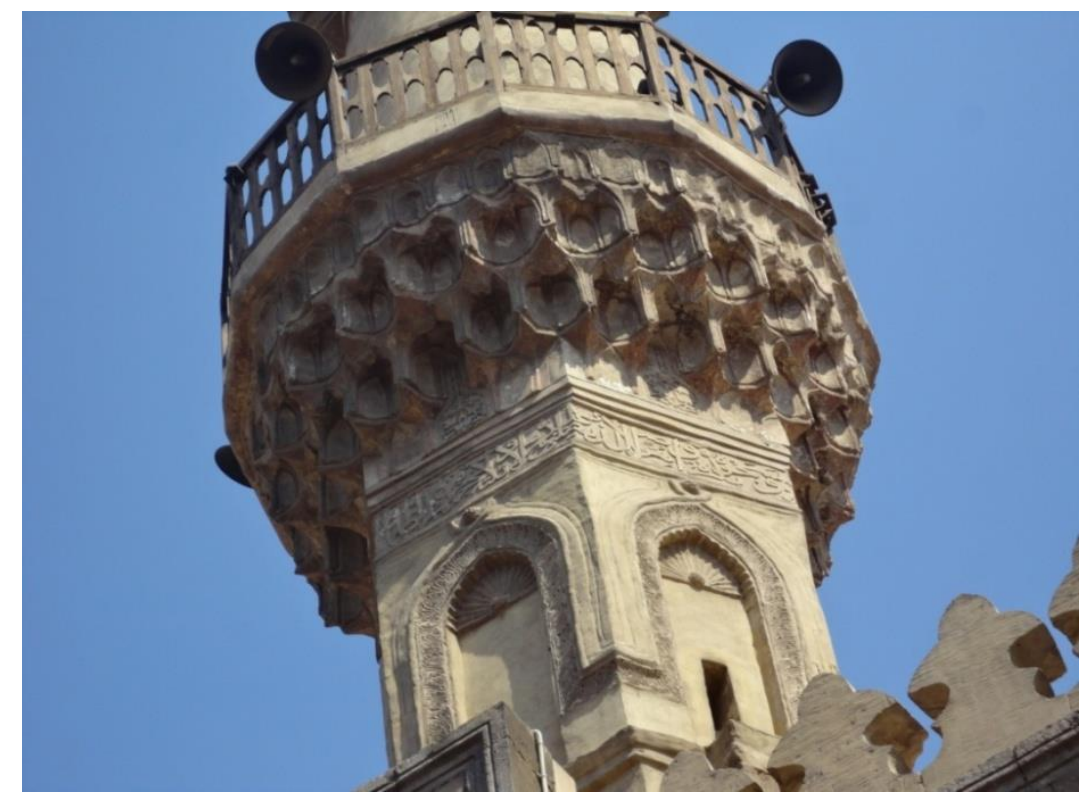

PL (5): Cairo, Al-Megharbilin Street, the era of the Circassian Mameluke, al-Amir Jani Beg al-Dawadar mosque, Inscription around the minaret It is a stone band of inscriptions in high-relief thuluth of a Qur'anic text, 830AH/1426-1427 AD.

\section{Sources, References, and Scientific Thesis}

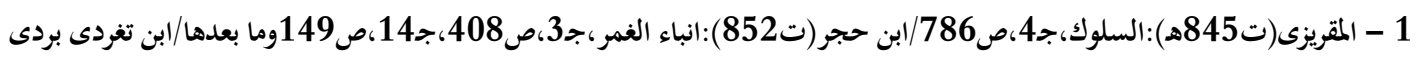

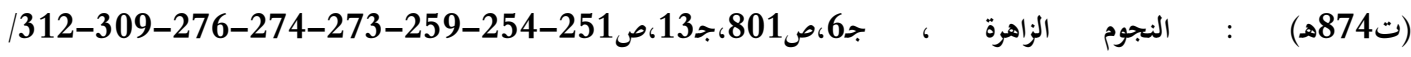

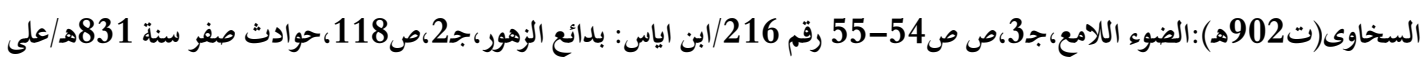

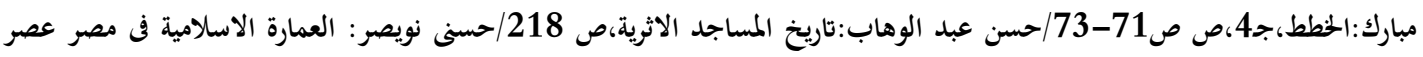

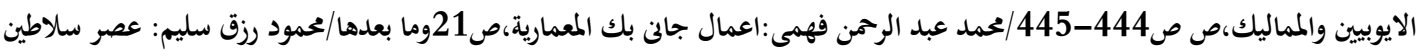

$$
\begin{aligned}
& \text { المماليك،مج1،ص189. }
\end{aligned}
$$

2 -This street was established after the over-crowdedness of Cairo since the era of the Caliph alHakim Bi-Amr Illah. It was also well reconstructed after the fire of Fustat, Askar and Qata'I at the end of the Fatimid era. It connects between the Fatimid Cairo and the capitals of ancient Egypt. In the Ottoman era, Radwan Bek paved the entrance of the street and built several constructions, so it was known as Qasabet Radwan.It is divided into three sections now, i.e., alKhayyamiyah (in the beginning), al-Migharbilin (in the middle) or al-Janabkiya (in attribution to Jani Beg) and al-Soroujiya (its end).

$$
\begin{aligned}
& \text { - حسنى محمد نويصر : المرجع السابق ، ص ص } 443 \text { - } 446 \text {-444. }
\end{aligned}
$$

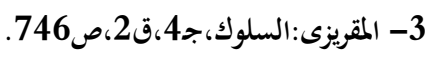

-Although Ali Mubarak mentioned that it was established in 828 AH See:

$$
\text { - 4- الحطط التوفيقية، ج4،صن حسب.72. }
$$


-Mohammed Fahmy pointed out that there was a sabil and a basin for drinking animals annexed to the mosque. He believed that the entrance vault led to another perpendicular one that ended with a well and some other annexes that are lost now. For more on their description, See:

- محمد فهمى:اعمال الامير جالن بك،ص صأ81-84.8

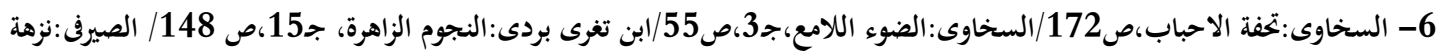

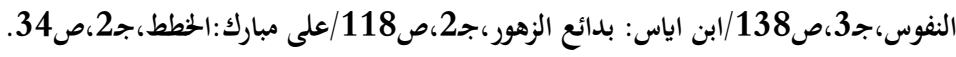
7-7 الخطط ، ج2.

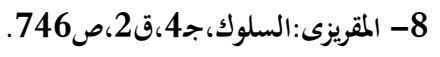

- Creswell : op. cit .p.124.Van Brchem: op. cit • p.363 / Mehre :Cahirenogkerafat, p.43.

9-There were madrassas and khanqahs in the same planning of congregational mosques, such as the Kharqah of Faraj ibn Barquq and madrassa of al-Mu'ayyad Sheikh.

- حسنى نويصر:المرجع السابق،ص446.

- Hassan Abdul Wahab stated that the establishment was designated due to its function not to the building itself - in terms of form and planning, i.e. the purpose for which it was built not the style of construction.

$$
\text { - حسن عبد الوهاب:المرجع السابق،ص14. }
$$

- For more on the controversy about the type of this construction, see:

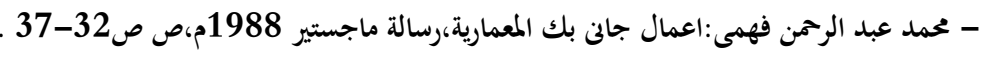

- After considering various viewpoints, he stated that it was conclusively a mosque according to its foundational text.

- And For more on the functional theory of constructions see:

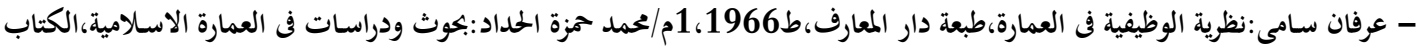

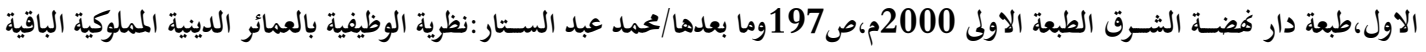

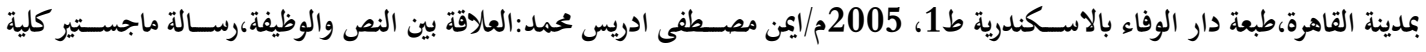

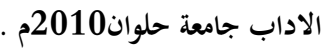

$$
\text { 10-حسن عبد الوهاب:المرجع السابق،صوان2010 }
$$

-For more on the restoration works, see the reports of the Arab Antiquities Preservation Committee:

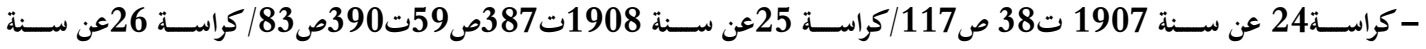

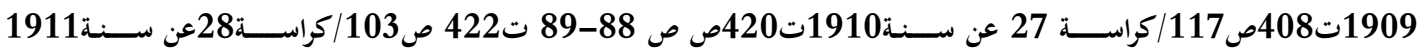

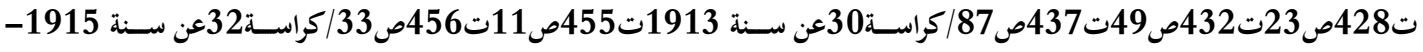

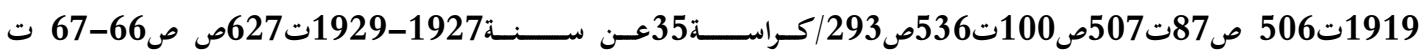

$$
\begin{aligned}
& \text { 627ص 72/كراسة } 40 \text { عن سنة 1946-1953 ت } 879 \text { ص } 77
\end{aligned}
$$

- And also the reports of National Archives:

$$
\text { - استبدال رقم 21/130 بدار الوثائق القومية بتاريخ 21ربيع لاول سنة 866هـ لاستبدال قطعة ارض موقوفة باخرى / حجة وقف رقم }
$$

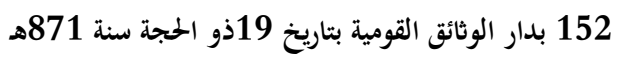

11 -He appears to be Nazir al-Jaysh (head of the army), al-Qadi Abdel Basset.

12 -For more description of the mosque, see:

$$
\text { - حسنى نويصر :المرجع السابق،ص450. }
$$

- محمد فهمى:المرجع السابق،ص ص37-84 


$$
\text { 13- محمد فهمى:المرجع السابق،ص43. }
$$

14 - Under the mosque there is a row of shops that are currently occupied. They are five complexes in different sizes, the largest is the eastward and it is used as a shop of selling furniture.

$$
\begin{aligned}
& \text { 15- حسنى نويصر :المرجع السابق، 1649. } \\
& \text { 16- المرجع السابق،صنئ نوبصر:المرجع. 149. }
\end{aligned}
$$

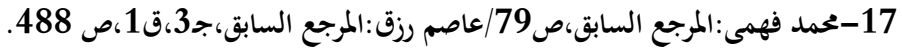

- And For more description of the minaret, see:

$$
\begin{aligned}
& \text {-عبد الله كامل موسى:الماذن،ص ص379-381- }
\end{aligned}
$$

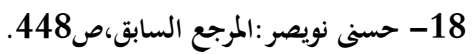

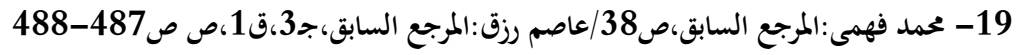

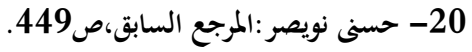

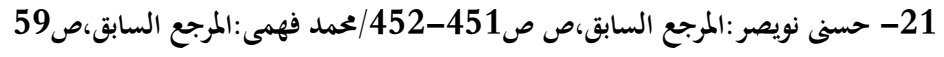

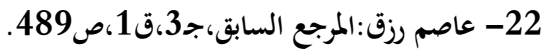

23- the researcher.

24- the researcher.

25 -Some of these texts were published before. See:

$$
\begin{aligned}
& \text { - حسن عبد الوهاب:المرجع السابق، ص218- 219/ عادل شريف علام:المرجع السابق،298/حسنى نويصر:المرجع }
\end{aligned}
$$

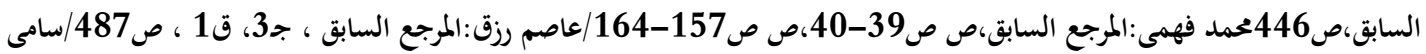

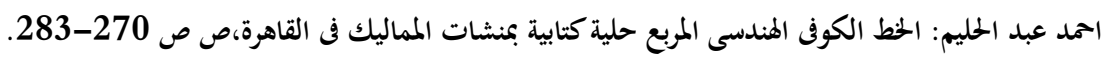

- Hautcoeur (L) et Wiet (G) : Les Mosquees du Caire (Paris1932) Tome I, P.p.312-318.

- Van berchem (M) : C.I.A. ( Paris 1903) Tome xi , P.360 .

-Meheren:Cahiratogkerafat, p.43 .

26-Sûrat AL-Jinn(The Jinn) -Verse:18.

27 -The square kuficinscriptionsspread were used on a large scale in the then mosques such as those found in the mosques of al-Mu'ayyad, Kafour al-Zemam, al-Jamali Yusuf and Fayrouz alSaqy.

$$
\text { - حسن عبد الوهاب:المرجع السابق،ص218 . }
$$

28 -It is a Quranic quote from Ayah 28 of Surah Al-Fath and 9 of Surah Al-Saff.

29-SûratFussilat (Explained in Detail) -Verse:30.

30-Sûrat AL-Baqarah(The Cow) -Verse:255.

31- This inscription is published here for the first time.

32-Sûrat AL-Ahzab (The Combined Forces) ) -Verses:41-44. 